\title{
Lung Function Status of Workers Exposed to Welding Fume: A Preliminary Study
}

\author{
Mulyana $^{1,2, *}$, Nuri Purwito Adi ${ }^{3}$, Meily L Kurniawidjaja ${ }^{4}$, Andi Wijaya ${ }^{1,5}$, Irawan Yusuf ${ }^{1}$ \\ ${ }^{1}$ Faculty of Medicine, Hasanuddin University, Jl. Perintis Kemerdekaan Km.10, Makassar, Indonesia \\ ${ }^{2}$ Prodia Occupational Health Institute, Jl. Kramat VI No.18, Jakarta, Indonesia \\ ${ }^{3}$ Faculty of Medicine, Universitas Indonesia, Jl. Salemba Raya No.6, Jakarta, Indonesia \\ ${ }^{4}$ Faculty of Public Health, Universitas Indonesia, Jl. Lingkar Kampus Raya Universitas Indonesia, Depok, Indonesia \\ ${ }^{5}$ Prodia Clinical Laboratory, Jl. Cisangkuy No.2, Bandung, Indonesia \\ *Corresponding author. E-mail: arsenicosa10@gmail.com
}

Received date: Mar 5, 2015; Revised date: Jul 13, 2015; Accepted date: Jul 16, 2015

\section{Abstract}

$\mathrm{B}$ ACKGROUND: Exposure to welding fume in the workplace was associated with lung function disorders and occupational asthma. In this study, we determined lung function parameters in men workers exposed to welding fumes from heavy equipment manufacturer. This study is a preliminary study of biomonitoring program in worker exposed to welding fume as our main study.

METHODS: A study with case-control design, random study, was conducted among welder (59 subjects) and nonwelder (34 subjects) with more than one year experience in the same job task in a heavy equipment manufacturer. All subjects completed physical examination, informed consent, questionnaire and lung function status. Lung function status was measured by spirometer with vital capacity (VC), forced vital capacity (FCV), forced expiratory volume in one second $\left(\mathrm{FEV}_{1}\right)$ and ratio of $\mathrm{FEV}_{1} / \mathrm{FVC}$ as test parameters. Linear regression model was developed to identify the risk factor of lung function parameter status using age, working period and smoking status as variables.

RESULTS: This study showed that there were significant lower $\mathrm{VC}, \mathrm{FVC}$ and $\mathrm{FEV}_{1}$ in welder than non-welder, but not difference in ratio of $\mathrm{FEV}_{1} / \mathrm{FVC}$. However, there was no significant difference among welder from foundry and fabrication plan. By multivariate analysis, working period was found as a risk factor for lower parameters in lung function among welder.

CONCLUSION: Lung function parameters status were significantly lower in welder than non-welder, and working period was the most important indicator for lung function status evaluation among welder.

KEYWORDS: vital capacity, VC, forced vital capacity, $\mathrm{FCV}$, forced expiratory volume in one second, $\mathrm{FEV}_{1}$, lung function, ratio of $\mathrm{FEV}_{1} / \mathrm{FVC}$, working period

Indones Biomed J. 2016; 8(1): 37-42

\section{Introduction}

Welding is a common process to join metals by heating them in welding temperature.(1) Welding processes produce hazardous agents including fumes, gases, vapors, heat, noise and ultraviolet and infrared radiation. The fume generated during welding are considered to be the most harmful compared with other byproducts of welding. Welding fume is the resulting vaporized metals that react with air to form complex metal oxides that are primarily of respirable size. The physical and chemical properties of the fume can vary depending on the materials and welding processes used.(2) Welding fume can induce adverse health effects, 
such as neurological (3) and respiratory diseases (4).

Occupational exposure to welding fume may cause several respiratory diseases such as occupational asthma, interstitial lung disease, bronchitis and chronic obstructive pulmonary disease (COPD). Interstitial lung disease reveals restrictive pulmonary function abnormality, whereas asthma and COPD generally show obstructive abnormalities on the spirometric test. Asthma and COPD are major cause of chronic mortality and morbidity worldwide and appropriate therapy with an early diagnosis of these diseases can significantly reduce socioeconomic burden and enhance patient quality of life. Many factors affect pulmonary status such as age, obesity (5), race and socioeconomic status (6) and smoking status (7). These factors can potentially act as confounders when evaluating the effect of welding exposure fume on pulmonary status impairment. Therefore, these factors should be considered when assessing the effect of welding fume to pulmonary status.

This is a preliminary as the part of major study, biomonitoring program in worker exposed to welding fume. We measured lung function status with some factors that could interfere lung function status such as age, working period and smoking status.

\section{Methods}

\section{Selection of Subjects}

This case-control design and random study was conducted among welder (22 subjects from foundry plan and 37 subjects from fabrication plan) and non welder (36 subjects) with more than one year experience in the same job task from heavy equipment manufacturer near Jakarta in 2014. The participating subjects were males and agreed to participate in the study after met to the inclusion and exclusion criteria. The welder task groups in this study included: foreman, fitter, cylinder officer, fitter, grinder, welder, foundry officer as welder, whereas office workers as non welder. The inclusion criteria were: aged between 18-55 years, agreed to undergo medical assessment test, and agreed to fill the informed consent form. The exclusion criteria were: central obesity, body mass index $\geq 30 \mathrm{~kg} / \mathrm{m}^{2}$, asthmatic history or familial asthmatic history, and eye, thorax or abdomen surgery history in one years ago. The data collection consisted of structured interview with questionnaire to inquire several information, such as bio-data, smoking history and date of birth. The study was approved by ethics committee of Faculty of Medicine, Hasanuddin University,
Makassar, Indonesia (approval number: 0131/H4.8.4.5.31/ PP36-KOMETIK/2015).

\section{Welding Type and Rod}

The most common type of welding processes used in this manufacturer is Manual Metal Arc Welding (MMAW), also known as Shielded Metal Arc Welding (SMAW). In this method, an electrode rod is used to create an electric arc that produces a high temperature which melts the base metal and the electrode to form a strong bond between the parent metal. Most rod used in welding process is solid wire which the content are 80-98\% iron, 1.1-1.95\% manganese, and other metals (copper, chromium, nickel, molybdenum and titanium $)<0.2 \%$.

\section{Lung Function}

A multi-functional spirometer (Chest MI serial HI-801, Japan) was used to measure the lung function status in this study. Before conducting maneuvers, there were some interviews to record the demographic data, smoking habit, working experience, symptoms and health history. The spirometer was calibrated with 1 L Chest precision syringe before and after the sessions to ensure correct measures. Vital capacity (VC), forced vital capacity (FCV), forced expiratory volume in one second $\left(\mathrm{FEV}_{1}\right)$ and ratio of $\mathrm{FEV}_{1} /$ FVC were recorded as lung function status parameters in accordance with American Thoracic Society guidelines. (10) Maneuvers were performed in a standing position with a nose clip and disposable mouthpieces which were used disposable for every individual. The highest lung function parameters value were chosen. Lung function parameters data were analyzed in absolute figures as well as percentage predicted from gender, age and height specific to Indonesia reference data, Pneumobile Project Indonesia.

\section{Statistical Analysis}

The normality of data distribution was tested with the Kolmogorov-Smirnov test. The differences in quantitative variables were tested with the parametric t-test or MannWhitney as alternative test, depend on data normality distribution. The parametric Pearson correlation test was used to investigate the relationship between concentrations of lung function parameters with age, working period and smoking status in welder group. Correlations with a Pearson correlation coefficient $(\rho)$ higher than 0.600 were considered strong correlation and those with a Pearson correlation coefficient ranging from 0.300 to 0.599 were considered medium correlation.(8) Linear regression was used for multivariate analysis from bivariate significant 
correlation. Statistical analyses were performed with SPSS, version 11.5. In all statistical analyses, two-sided $p$ values of 0.05 were considered as significant.

\section{Results}

General characteristics of the study population are summarized in Table 1. In total, 95 subjects (59 welders and 36 non-welders) were involved in this study. Age median was lower in non-welder but not significant. The working period in welder group was significant longer than non welder. The antrophometric parameters of non welder group were significant higher than welder. The spirometric variables of welder were significant lower than non-welder, except ratio of $\mathrm{FEV}_{1} / \mathrm{FVC}$.

We compared the spirometric parameters in welder from foundry plan and fabrication plan were not significant difference $(p>0.05)$. The spirometric parameters analysis from foundry and fabrication plan was sumarized in Table 2.

In welder, corelation analysis regarding spirometric pamaters were significantly correlated with age and working period however no significant correlation between spirometric parameters with smoking status. The analysis of correlation between spirometric parameters with age, working period and smoking status were summarized in Table 3.

Table 1. Demographic characteristics of the study group stratified by occupation.

\begin{tabular}{lccc}
\hline \multicolumn{1}{c}{ Variable } & $\begin{array}{c}\text { Non Welder } \\
(\mathbf{N = 3 6 )}\end{array}$ & $\begin{array}{c}\text { Welder } \\
(\mathbf{N = 5 9 )}\end{array}$ & $\boldsymbol{p}$ \\
\hline Age (year) & $26(22-52)$ & $33(21-47)$ & 0.09 \\
Working period (year) & $4.0(1-27)$ & $10.0(1-24)$ & $0.025^{* *}$ \\
Height (m) & $1.69 \pm 0.08$ & $1.66 \pm 0.06$ & $0.008^{*}$ \\
Weight $(\mathrm{kg})$ & $67.91 \pm 9.59$ & $60.66 \pm 8.16$ & $0.000^{*}$ \\
BMI $\left(\mathrm{kg} / \mathrm{m}^{2}\right)$ & $23.65 \pm 2.78$ & $22.07 \pm 3.06$ & $0.016^{*}$ \\
Smoking status & & & \\
$\quad$ Non-smoker & $29(82.86)$ & $25(46.30)$ & - \\
$\quad$ Ex-smoker & $1(2.86)$ & $6(11.11)$ & - \\
$\quad$ Current smoker & $5(14.29)$ & $28(51.85)$ & - \\
VC (L) & $3.67 \pm 0.67$ & $3.34 \pm 0.53$ & $0.012^{*}$ \\
FVC (L) & $3.41 \pm 0.62$ & $3.02 \pm 0.48$ & $0.001^{*}$ \\
FEV $(\mathrm{L})$ & $3.77 \pm 0.69$ & $3.38 \pm 0.53$ & $0.003^{*}$ \\
Ratio of FEV $_{1} / \mathrm{FVC}$ & $90.67 \pm 5.34$ & $89.39 \pm 4.87$ & 0.221 \\
\hline
\end{tabular}

* T Test; ** Mann- Whitney U

Table 2. Spirometric parameters in welder stratified by location of exposure.

\begin{tabular}{lccc}
\hline \multicolumn{1}{c}{ Variable } & $\begin{array}{c}\text { Foundry } \\
(\mathbf{N = 2 2})\end{array}$ & $\begin{array}{c}\text { Fabrication } \\
(\mathbf{N}=\mathbf{3 7})\end{array}$ & $\boldsymbol{p}^{*}$ \\
\hline $\mathrm{VC}(\mathrm{L})$ & $3.38 \pm 0.36$ & $3.26 \pm 0.61$ & 0.547 \\
$\mathrm{FVC} \mathrm{(L)}$ & $3.40 \pm 0.38$ & $3.31 \pm 0.61$ & 0.712 \\
$\mathrm{FEV}_{1}(\mathrm{~L})$ & $3.01 \pm 0.33$ & $2.97 \pm 0.56$ & 0.949 \\
${\text { Ratio of } \mathrm{FEV}_{1} / \mathrm{FVC}}$ & $88.63 \pm 3.43$ & $89.66 \pm 5.10$ & 0.37 \\
\hline
\end{tabular}

* T Test 
Table 3. Correlation analysis between spirometric paramaters and the risk factors.

\begin{tabular}{lccc}
\hline \multicolumn{1}{c}{$\begin{array}{c}\text { Spirometric } \\
\text { Parameters }\end{array}$} & Age (year) & $\begin{array}{c}\text { Working Period } \\
\text { (year) }\end{array}$ & $\begin{array}{c}\text { Smoking } \\
\text { Status }\end{array}$ \\
\cline { 2 - 4 } & $-0.383 *$ & -0.394 & 0.007 \\
VC (L) & $-0.395 *$ & -0.404 & 0.047 \\
FVC (L) & $-0.493 *$ & $-0.504 *$ & 0.087 \\
FEV1 (L) & $-0.362 *$ & $-0.365 *$ & 0.125 \\
Ratio of FEV FVC $_{1}$ F & & & \\
\hline
\end{tabular}

* Pearson correlation test

Table 4. Regression analysis between spirometric paramaters and the risk factors.

\begin{tabular}{|c|c|c|c|c|c|}
\hline Model & $\begin{array}{c}\text { Standarized } \\
\text { Coefficient } \\
\text { Beta }\end{array}$ & $95 \%$ CI & $\mathbf{t}$ & $\mathbf{R}^{2}$ & $p$ \\
\hline \multicolumn{6}{|l|}{$\mathrm{VC}(\mathrm{L})$} \\
\hline Working period (year) & -0.394 & -0.04 to -0.009 & -3.235 & 0.155 & $0.002 *$ \\
\hline \multicolumn{6}{|l|}{ FVC (L) } \\
\hline Working period (year) & -0.404 & -0.041 to -0.01 & -3.333 & 0.163 & $0.002 *$ \\
\hline \multicolumn{6}{|l|}{$\mathrm{FEV}_{1}(\mathrm{~L})$} \\
\hline Working period (year) & -0.504 & 0.042 to -0.016 & -4.403 & 0.254 & $0.000 *$ \\
\hline \multicolumn{6}{|l|}{ Ratio of $\mathrm{FEV}_{1} / \mathrm{FVC}$} \\
\hline Working period (year) & -0.365 & -0.329 to -0.063 & -2.96 & 0.133 & $0.004 *$ \\
\hline
\end{tabular}

*Linear regression analysis

We used multivariate analysis with regression linear test, only working period was the risk factor for lower lung function parameters in our study. The multivariate analysis were summarized in Table 4.

\section{Discussion}

This study is a part of biomonitoring program among workers exposed to welding fume. The assessment of lung function with a spirometer has become common practice in occupational medicine.(10) Lung function is an essential role in epidemiological studies investigating the incidence, natural history and causality of occupational and environmental lung disease. Consistent with previous studies $(9,11,12)$, our study also demonstrated a lower of
VC, FVC, and FEV1 but not significant FEV1/FVC ratio in welder than non welder as control group. We exclude some medical conditions such as obesity, and asthmatic history. In this study we did not found occupational asthma among the workers.

In welder group, lung function parameters was divided by fabrication and foundry plan. The activities in fabrication plan are assembling many parts, grinding, fitting, cylinder activity and gauging. The main activities in foundry plan are smelting, molding, grinding and welding. Most worker was exposed by welding fume from assembling and gauging, and many metals dust from grinding. There were no different significant of lung function parameters after stratification by plan location $(p>0.05)$. Unfortunately, no data available for metal fume level around the working area of the plans. The previously studies; chromium (11), manganese (12), and 
iron (13), fume induced lung function disorder. Every metal fume has different mechanism to induce lung toxicity.

Correlation analysis between lung function status parameters with age and working period among welder group were significant. In regression analysis, we found that only working period as a predictor variable for lung function disorder. We did not found restrictive or obstructive lung function in welder. In previous study, obstructive lung function test correlated with iron fume and welding fume, but did not correlated with smoking status.(14) In this study we did not find the correlation between lung function parameters and smoking status. Most studies indicate smoking status accelerate decline lung function in welder with very big sample size $(\mathrm{n}>4000)(15)$, and in obstructive type lung disorder $(16,17)$. We suggest to determine cotinine plasma level test for smoking status indicator. $(18,19)$

Some environmental factors from automotive emission and industrial emission could affect lung function status however this factor did not analyze in our study. Automotive and industrial emission contain particulate matter, nitrogen oxide, sulfur dioxide etc will affect lung function.(20)

There were some limitation that should be noted in this study. Firstly, it was difficult to evaluate the effect of working period as the exact calculation because the complexity of jobs histories. However, event in simple occupational histories, the effects of working period may be obscured by the effect of aging. Secondly, the obedience of using personal protective devices also were quite different for every worker even in their working time. At the present, all workers were exposed to welding fume or metal fume wore personal protective devices. Thirdly, the content of exposure from welding fume as the level of exposure were not assessed.

\section{Conclusion}

In summary, lung function parameters were significantly correlated with working period in welder exposed to welding fume. This finding suggests that working period exert lung function status in worker exposed welding fume, evaluation and caring management for lower lung function workers.

In further study will be conducted to explain the biopathology mechanism of welding fume that induce lower lung function status. Authors declare no conflict of interest.

\section{References}

1. Antonini JM, Santamaria AB, Jenkins NT, Albini E, Lucchini R. Fate of manganese associated with the inhalation of welding fumes: potential neurological effects. Neurotoxicology. 2006; 27: 304-10.

2. Antonini JM, Roberts JR, Chapman RS, Soukup JM, Ghio AJ, Sriram K. Pulmonary toxicity and extrapulmonary tissue distribution of metals after repeated exposure to different welding fumes. Inhal Toxicol. 2010. 22: 805-6.

3. Yu IJ, Park JD, Park ES, Song KS, Han KT, Han JH, et al. Manganese distribution in brains of Sprague-Dawley rats after 60 days of stainless steel welding-fume exposure. Neurotoxicology. 2003; 24 777-85.

4. Yoon CS, Paik NW, Kim JH. Fume generation and content of total chromium and hexavalent chromium in flux-cored arc welding. Ann Occup Hyg. 2003; 47: 671-80.

5. Salome CM, King GG, Berend N. Physiology of obesity and effects on lung function. J Appl Physiol. 2010; 108: 206-11.

6. Van Sickle D, Magzamen S, Mullahy J. Understanding socioeconomic and racial differences in adult lung function. Am J Resp Crit Care Med. 2011; 184: 521-7.

7. Anthonisen NR, Connett JE, Murray RP. Smoking and lung function of Lung Health Study participants after 11 years. Am J Resp Crit Care Med. 2002; 166: 675-9.

8. Artusi R, Verderio P, Marubini E. Bravais-Pearson and Spearman correlation coefficients: meaning, test of hypothesis and confidence interval. Int J Biol Markers. 2002; 17: 148-51.

9. Sharifian SA, Loukzadeh Z, Shojaoddiny-Ardekani A, Aminian O. Pulmonary adverse effects of welding fume in automobile assembly welders. Acta Med Iran. 2011; 49: 98-102.

10. Townsend MC, Occupational and Environmental Lung Disorders Committee. Spirometry in the occupational health setting -- 2011 update. J Occup Environ Med. 2011; 53: 569-84.

11. Walters GI, Moore VC, Robertson AS, Burge CB, Vellore AD, Burge PS. An outbreak of occupational asthma due to chromium and cobalt. Occup Med. 2012; 62: 533-40.

12. Bowler RM, Roels HA, Nakagawa S, Drezgic M, Diamond E, Park $\mathrm{R}$, et al. Dose-effect relationships between manganese exposure and neurological, neuropsychological and pulmonary function in confined space bridge welders. Occup Environ Med. 2007; 64: 16777.

13. Patel RR, Yi ES, Ryu JH. Systemic iron overload associated with Welder's siderosis. Am J Med Sci. 2009; 337: 57-9.

14. Ryu JY, Lee SY, Kim DH. Obstructive pulmonary function impairement among Korean male workers exposed to organic solvents, iron oxide dust, and welding fumes. Ind Health. 2013; 51: 596-602.

15. Harbison SC, Johnson GT, McCluskey JD, Xu P, Mohammad S, Wolfson $\mathrm{J}$, et al. Occupational health surveillance: Pulmonary function testing in utility workers. J Clinic Toxicol. 2012; S5: 006. doi: 10.4172/2161-0495.S5-006.

16. Paulose-Ram R, Tilert T, Dillon CF, Brody B. Cigarette smoking and lung obstruction among adults aged 40-79: United States, $2007-$ 2012. NCHS Data Brief. 2015; 181: 1-8.

17. Mohamed Hoesein FA, de Hoop B, Zanen P, Gietema E, Kruitwagen $\mathrm{CL}$, van Ginneken B, et al. CT-quantified emphysema in male heavy 
smokers: association with lung function decline. Thorax. 2011; 66: 782-7.

18. Rodriguez J, Jiang R, Johnson WC, MacKenzie BA, Smith LJ, Barr RG. The association of pipe and cigar use with cotinine levels, lung function, and airflow obstruction: a cross-sectional study. Ann Intern Med. 2010; 152: 201-10.
19. Flouris AD, Chorti MS, Poulianiti KP, Jamurtas AZ, Kostikas K, Tzatzarakis MN, et al. Acute impact of active and passive electronic cigarette smoking on serum cotinine and lung function. Inhal Toxicol. 2013; 25: 91-101.

20. Sakti ES, Djaya IM. Tinjauan tentang kualitas udara ambient (NO2, $\mathrm{SO} 2$ dan total suspended particulate) terhadap kejadian ISPA di kota Bekasi. Skripsi. Universitas Indonesia; 2012. 